\title{
Věk v sociologické teorii: Perspektiva životního běhu
}

\author{
Age in Sociological Theory: The Life Course Perspective \\ Jana Havlíková
}

ABSTRACT In the early 1960 s, the life course theory emerged as one of the fundamental concepts in the domain of social sciences in Europe and North America. Since that time, this perspective has provided a new theoretical approach to understanding social reality with important methodological implications. On the basis of the life course theory, individual lives are studied in their whole - from birth to death. Furthermore, life course theory takes into account both macro and micro levels of social reality, so that the dynamic relationship between the individual and society can be examined. Individuals are thus seen as active and creative agents able to shape their lives.

Nevertheless, the life course perspective is not yet well known among Czech social scientists. Therefore the main aim of this article is to introduce life course theory into this geographical zone. First, we briefly describe the genesis of the concept. Then we point out that the term "life course" used to be applied in a variety of meanings in scientific literature, which sometimes causes difficulties in understanding its content. We have identified three levels of application of the term "life course": as a paradigm, as an analytical concept and as a social institution. These lines of meaning are elaborated here with a special focus on their definitions, key notions and methodological consequences. Finally, in the case of the life course as an institution, we discuss its evolution in the context of postindustrial societies.

KEY WORDS Life course - institution, life course - theory, life course - paradigm

\section{Úvod aneb Jak se sociologové začali zajímat o životní běh}

Ve společenském kontextu hospodářsky rozvinutých zemí, zvláště pak na evropském kontinentě, je možné nebýt sudičkou či vědmou, a přesto stát u postýlky nově narozeného dítěte a v hlavních obrysech a s vysokou mírou pravděpodobnosti předpovědět, jaké významné události a kdy, přsesněji v kolika letech života se tomuto dítěti přihodí.

Pravidelnosti v běhu životních událostí jednotlivých lidí, které nebylo možné vysvětlit prostě jen odkazem na biologické stárnutí člověka, ale bylo lze tušit jejich sociální původ, se postupně staly předmětem zájmu sociálních věd. Počátky formování teoretického uchopení dynamiky každodenního života jedinců a procesu stárnutí spadají přitom v sociálních vědách do období mezi dvěma světovými válkami (Mayer 2004). Toto údobí se nese v duchu hledání vhodného pojmosloví pro zachycení dynamické povahy lidského života: psychologové přicházejí s pojmy „vývoj“ a ,životní cyklus“, sociologové zase s koncepty ,životní historie“ a „generace“. Koncept životního běhu byl poprvé vymezen až v 60. letech 20. sto-

Sociální studia. Fakulta sociálních studií Masarykovy univerzity, 1-2/2007. S. 179-200. ISSN 1214-813X. 
letí Leonardem Cainem (1964: 278) v tom smyslu, že životní běh „odkazuje k oněm po sobě jdoucím individuálním statusům, jejichž zaujímání je od jedinců v různých kulturách a sociálních skupinách očekáváno v souvislosti se stárnutím“.

Ačkoliv Marshall s Muellerovou (2003) považují Caina za toho, kdo poprvé použil termín a zformuloval první verzi konceptu životního běhu, on sám se patrně za zakladatele paradigmatu nepovažoval. Jednak uvádí, že geneze tohoto prŕstupu ke studiu společnosti a zvláště věku jako prvku sociální struktury sahá již k počátku 20. století. A dále, Cain s tímto pojmem pracuje, ačkoli prŕliš nediskutuje jeho obsah a ani se nezabývá jeho vymezením vůči obsahově příbuzným pojmům, které byly v jeho době používány - jako jsou životní cyklus, stárnutí, životní stadia aj. -, jen uvádí, že jde více či méně o synonyma. Celkově užití tohoto pojmu v jeho textu vyvolává dojem, že termín životní běh byl vytvořena spíše ad hoc. Jednalo se však o pojem, který určitým způsobem odrážel dlouholeté zaujetí části sociálních vědců pro utváření životních vzorců ve společenském kontextu. V sociálních vědách se uchytil a byl a je dále rozvíjen, upřesňován, kritizován a redefinován.

Od uvedení hesla „Life Course and Social Structure“ v Handbook of Modern Sociology (1964) lze pozorovat systematický rozvoj konceptu životního běhu. Na jeho základě začínají být individuální životy zkoumány v jejich celistvosti, tedy od narození po stáŕí, jako dynamické prvky sociální struktury. Individuální životní běh je pak vnímán jako výslednice vzájemných interakcí mezi jedincem a společností. Společenský kontext představují jak individuální sociální sítě, tak celospolečenský institucionální rámec, který byl primárně odvozen od hospodářské produkce. Následný vývoj konceptu životního běhu a jeho rozšíření ve svébytné paradigma zahrnuje vydělení dvou hlavních teoretických a především výzkumných proudů. Spíše psychologicky orientované pojetí typické pro USA akcentuje individuální aktivitu jedinců a biografický př́stup. Naopak sociologická větev charakteristická pro evropský kontext zdůrazňuje vliv sociálních institucí, zvláště sociálního státu, na výslednou podobu instituce životního běhu a využívá i kvantitativních metod zkoumání. Postupně však dochází ke sblížení a vzájemnému obohacení obou větví - k uznání vlivu institucionálního rámce alespoň v určitých životních situacích na severoamerické straně (Arnett 2006, Mortimer a Larson 2002) a k nutnosti zaměřit se na roli individuálního aktéra v utváření životního běhu na straně evropské (Heinz a Krüger 2001).

V české sociologii představuje teorie životního běhu poměrně nový a nikoliv běžně známý prvek. Na přelomu 80. a 90. let 20. století se jí věnoval Josef Alan (1989), nicméně jeho publikace byla spíše ojedinělým počinem. Zájem o teorii životního běhu se opět pozvolna probouzí ve 21. století, a sice například v souvislosti s biografickou sociologií či s tématy stárnutí, generace apod.

Následující text si klade za cíl seznámit českou odbornou veřejnost s teorií životního běhu a poskytnout př́ipadným zájemcům o ni základ pro další studium. S ohledem na tento záměr byl zvolen převážně přehledový formát statě. Nejprve se věnujeme určení významů, v nichž se termín životního běhu v odborné literatuře vyskytuje. Je jich více a často jsou užívány bez upozornění čtenáře, o kterou rovinu významu se právě jedná, což „začátečníkům“ znesnadňuje čtení a pochopení daných textů. Identifikované linie významů jsou pak dále upřesněny z hlediska jejich definice, teoretické role, metodologických implikací a v případě životního běhuinstituce jsou diskutovány i jeho proměny v post-industriálních společnostech. 


\section{Životní běh - obtíže s vymezením pojmu}

Na tomto místě patrně čtenář očekává odpověd' na otázku: O čem sociální vědci vlastně hovoří, když mluví o životním běhu?, neboli definici tohoto pojmu. Předložit jednotnou definici životního běhu však není snadné, nebo lépe řečeno, je to nemožné.

Začteme-li se do odborné literatury na toto téma, pak zjistíme, že ačkoliv se všichni autoři nějakým způsobem k životnímu běhu vztahují, často se ve svém pojetí životního běhu liší. Někdy ho používají jako prostředku k zachycení či popisu určité sociální reality, jindy na jeho základě stanovují výzkumný design a vysvětlující vztahový rámec, a ještě jindy je sám objektem zkoumání coby sociální jev.

Na první pohled by se mohlo jevit, že je-li chápání a aplikace nějakého pojmu takto široká, je naprosto nesmyslné s takovým pojmem vědecky pracovat, nebot' každý autor ho užívá po svém a snad jím i maskuje nedostatečné teoretické uchopení problematiky, kterou se zabývá. Nicméně pohledem druhým přeci jen odhalujeme jisté pravidelnosti v užívání tohoto termínu, a sice spatřujeme tři vnitřně relativně kompaktní linie aplikace pojmu životní běh jako analytického konceptu, jako sociálně-vědního paradigmatu a jako sociální instituce ve smyslu sociálního faktu. Přesněji určit tyto linie se pokusíme v následujících podkapitolách. Ačkoliv historický vývoj postupoval spíše od pojetí životního běhu jako analytického konceptu směrem k paradigmatu, přesto se nejprve věnujeme právě paradigmatické perspektivě, nebot' v jejím rámci je koncept životního běhu nejčastěji uplatňován. Hodláme tedy postupovat od obecných východisek přes specifický teoretický koncept až k prvku sociální reality, to vše pod heslem ,životní běh“.

\section{Životní běh jako paradigma}

Elder (1994, 1995) byl zřejmě první, kdo označil životní běh jako metodologické paradigma. Definuje totiž obecné pole zkoumání tím, že poskytuje rámec, který vede výzkum v termínech identifikace a formulace předmětu výzkumu, výběru a zdůvodnění proměnných a strategie projektování a analýzy. Posléze je životní běh uváděn i jako paradigma bez dalšího př́vlastku, nebot' tento pohled na sociální realitu v sobě nese i řadu epistemologických předpokladů a důsledků. Životní běh coby paradigma přináší specifický teoretický pohled na dialektický vztah mezi jedincem a společností. Integruje makro- a mikrosociální roviny společenské struktury s dynamickým prvkem, a propojuje tak koncepty sociální změny, sociální struktury a individuálního jednání. Vnímání životního běhu jako paradigmatu se pak ve vědecké komunitě rozšíŕilo.

Obecně lze říci, že teorie životního běhu sleduje $\mathrm{v}$ př́istupu $\mathrm{k}$ sociální realitě tyto tři základní principy:

1. holistické pojetí života jedince ve společnosti, ${ }^{1}$

2. jedinec a sociální struktura se vzájemně ovlivňují,

Nicméně Settersten a Mayer (1997) argumentují, že holistický přístup se již ze studií životního běhu v podstatě díky jejich rostoucí specifické zaměřenosti vytratil. Fragmentace výzkumného pole již neprobíhá jen napříč vědeckými disciplínami, ale i uvnitř nich. 
3. tato vzájemná interakce významně souvisí s věkem (chronologickým, sociálním, historickým).

Přičemž právě třetí bod - teoretické i metodologické zohlednění dimenze času a procesu individuálního stárnutí - vymezuje sociologii životního běhu vůči ostatním sociologickým paradigmatům (Kohli 1985).

Tato teoretická perspektiva klade rovněž specifické nároky na metodologii. Jelikož se snaží zachytit lidský život v jeho celistvosti a usiluje o to z komplexních vztahů mezi jedincem a společností vysvětlit jeho průběh, vyžadují analýzy určitý typ dat, a sice data biografická a longitudinální. Přičemž jsou využívány jak kvalitativní, tak kvantitativní metody zkoumání a často i kombinace obého (Heinz 2003). Paradigma také klade nároky na výzkumníkovu obeznámenost s historickým a institucionálním kontextem daných biografií (srov. oddíl Dimenze...).

$\mathrm{Na}$ jakých předpokladech tedy staví paradigma životního běhu a v čem vlastně spočívá jeho multidimenzionální podoba? Na tyto otázky se zaměřujeme v následujících dvou oddílech.

\section{Východiska paradigmatu životního běhu}

Kromě výše zmíněných základních principů vymezujících paradigma životního běhu existuje ještě řada víceméně $\mathrm{v}$ rámci paradigmatu nezpochybňovaných předpokladů, od nichž se odvíjí výkladový rámec této perspektivy. Bez uvědomění si těchto východisek a bez jejich bližšího pochopení lze jen obtížně s touto teorií pracovat a rozumět výstupům na ní založených, nebot' autoři, ačkoliv s nimi pracují, často je již blíže neobjasňují. Zmíněná východiska lze rozdělit do dvou skupin. První skupina zahrnuje předpoklady o roli času v lidském životě. Druhá skupina pak obsahuje předpoklady o povaze sociální reality - představuje konceptualizaci prostoru interakcí mikro a makro roviny sociální reality, jejichž výslednicí je konkrétní životní běh. Touto druhou skupinou východisek se podrobně zabýváme v samostatném oddíle Dimenze..., nebot' její prvky současně tvoří jádro takzvaného Elderova čtyřdílného paradigmatu životního běhu. V následující části se tedy detailněji věnujeme první skupině předpokladů.

Východiska týkající se významu času pro lidský život, které jsou v rámci paradigmatu Životního běhu identifikována a zohledňována, lze shrnout ve čtyřech bodech: ${ }^{2}$

1) stárnutí jako výslednice tři typů procesů - biologického, psychického a sociálního;

2) stárnutí jako celoživotní proces;

3) diferencovaný pohled na věk;

4) dynamický pohled na stadia lidského života.

Tři roviny stárnutí, a sice rovina biologická, sociální a psychologická, jsou považovány za vzájemně provázané a významně ovlivňující konkrétní podobu životního běhu. Biologický proces stárnutí pozorujeme na úrovni jedince-organismu. Fyzické tělo umožňuje jedinci na

2 První dvě uvedená východiska byla převzata od Mathildy Riley a kol. (1972) ze sociologie věkové diferenciace. 
jedné straně bytí ve společnosti, na druhé straně však s sebou nese četná omezení. ${ }^{3}$ Dále sociální proces stárnutí odkazuje ke společensky definované věkové struktuře a věkovým normám. Věkové normy vymezuje Elder (1975) jako normativní očekávání těšící se společenskému konsensu. Tato očekávání se pojí vždy k určitému chronologickému věku jedince a specifikují vhodné chování, role a časový rozvrh životních událostí. Věkové normy jsou rovněž významné pro sebehodnocení jedince a vytvářejí základ normativního modelu životního běhu (viz oddíl Normativni model...). Proces stárnutí na úrovni psychické pak představuje pole zájmu psychologie, zvláště vývojové psychologie. $\mathrm{Z}$ hlediska sociologie tak stojí poněkud mimo zorné pole. Výzkumník tedy musí brát $\mathrm{v}$ úvahu tři prostory do jisté míry svébytné, ale vzájemně provázané, v nichž se proces stárnutí odehrává. Dokonce lze hovořit o třech typech procesu stárnutí, nebot' každý z nich je řízen jinými činiteli a všechny tři mají odlišnou dynamiku.

Druhý z předpokladů se rovněž týká stárnutí, nicméně již ne jeho struktury, ale místa, které zaujímá v rámci celého individuálního životního běhu. Paradigma životního běhu chápe spolu s Riley a kol. (1972) stárnutí jako celoživotni proces získávání zkušeností, který začíná narozením a končí smrtí jedince. Stárnutí tedy není vnímáno jako záležitost pouze, řekněme, poslední třetiny života, ale jako vývoj jedince $\mathrm{v}$ čase.

Paradigma životního běhu nenabízí jen specifické pojetí fenoménu stárnutí, ale je mu vlastní také diferencovaný pohled na věk jedince. Věk vůbec hraje v rámci tohoto paradigmatu ústřední roli. Je to proto, že sociální struktura moderní společnosti je v podstatě organizována v závislosti na věku (viz například vzdělávací systém, oprávnění pracovat, uzavírat sňatek nebo vlastnit řidičský průkaz). Analyticky však věk jedince neodkazuje pouze k jedné skutečnosti, nýbrž v sobě skrývá tři různé dimenze (Elder 1975, Riley a kol. 1972):

a) Individuální životni čas, nebo také chronologický či biologický věk slouží jako hrubý ukazatel životního stádia a stárnutí.

b) Sociálni věk odkazuje ke společenské konstrukci významu biologického věku, obsahuje tedy intersubjektivně sdílená normativní očekávání ohledně vhodných rolí a jednání v závislosti na určitém biologickém věku. Rovněž disponuje odměnami a sankcemi, které slouží k povzbuzení jedince, aby svůj životní běh konstruoval v souladu $\mathrm{s}$ těmito věkovými normami. Tak je mateřství ve 14 letech chápáno jako př́liš brzké a ve 45 letech zase jako opožděné.

c) Historický věk umistuje jedince na základě jeho roku narození do konkrétní historické doby a konkrétního místa, jejichž možnosti a omezení ovlivňují výslednou podobu jeho životního běhu. Je totiž rozdíl mezi tím, zda někdo prožil válku jako dítě, nebo jako mladý dospělý atd.

Tyto odlišné významy věku jsou pak reflektovány v jednotlivých dimenzích životního běhu, tak jak ho pojímají Giele a Elder (viz Dimenze...).

Poslední, avšak nezanedbatelná premisa životního běhu se skrývá pod pojmem dynamický pohled na stadia lidského života. Giele a Elder (1998: 17) vysvětlují tuto perspekti-

U pojmů, které jsou specifické pro teorii životního běhu, uvádíme v závorkách i jejich anglické ekvivalenty. Činíme tak s ohledem na to, že česká terminologie dosud není zcela ustálená a bez odkazu k originálním názvům by mohlo dojít ke zmatení čtenáře. 
vu následovně: „Jakýkoliv bod v životě je chápán jako výslednice minulé zkušenosti a budoucích očekávání a současně jako výslednice integrace individuálních motivů a vnějších omezení.“"

Zmíněný princip se tedy již netýká přesvědčení o vnějších podmínkách utváření životního běhu, ale naopak postuluje jedince jako aktivního činitele, skrze jehož rozhodnutí a jednání se zmíněné zkušenosti, očekávání, motivy a omezení promítají do podoby individuálního životního běhu. Současně je v něm obsažen dynamický prvek, nebot' propojuje jak vertikální (minulost - př́tomnost - budoucnost), tak horizontální (přítomná přání a limity) osu života jedince. Rovněž klade požadavek na začlenění biografií do výzkumného designu.

\section{Dimenze životního běhu podle Eldera a Giele}

Konkrétní podoba životního běhu je v každém bodě výslednicí vzájemné interakce makro- a mikrosociální struktury. Elder a Giele (1998) identifikovali čtyři klíčové dimenze, skrze něž je možné uchopit dialektické procesy probíhající mezi uvedenými dvěma rovinami sociální reality. Tyto dimenze současně vytvářejí konečnou podobu životního běhu: ${ }^{4}$

1) Umistění v čase a prostoru (historické a kulturni zázemí): odkazuje $\mathrm{k}$ historické době, v níž se životy jedinců odvíjely, $\mathrm{k}$ její sociální struktuře a kulturěe.

2) Propojené životy (sociální integrace): jsou výsledkem interakce individuí s blízkým sociálním prostředím, v němž jsou jejich životy zasazeny, zvláště s př́ibuznými a práteli.

3) Lidské jednání (individuální orientace na cill): představuje aktivní úsilí o dosažení individuálních cílů (například ekonomického zajištění) a osobní identity.

4) Načasování (strategická adaptace): načasování životních událostí - tj. zvolení vhodné doby pro akumulaci nebo využívání zdrojů (různých druhů kapitálů) - je možno chápat jako strategickou adaptaci na vnější podmínky sledující dosažení zvoleného cíle.

Vzájemné propojení uvedených dimenzí paradigmatu životního běhu a jejich vyústění v konkrétní podobu individuálního života ilustruje Obrázek 1. Stojí za povšimnutí, že čtvrtá dimenze - načasování - funguje jako syntetizující prvek a jako jistá forma překladu zbylých trrí dimenzí, která vytvárí další větu v celém životním příběhu. Dimenze životního běhu vlastně představují rozkrytí struktury sociálních vztahů a vlivů, které v každém bodě života formují jeho konkrétní podobu - podobu, která vyvěrá z předchozího utváření životního běhu jedincem a zároveň do jisté míry předurčuje i jeho budoucí obrysy (srov. dynamický princip výše).

Sledujeme-li např́klad trajektorii vzdělání - konkrétně volbu střední školy -, pak lze předpokládat, že výborný prospěch žáka na základní škole (minulé události) ho povzbudí $\mathrm{k}$ volbě gymnázia jako další školy (přítomnost). Studium gymnázia současně s velkou pravděpodobností predikuje účast tohoto žáka i na některém z typů terciárního vzdělávání, což znamená, že tato osoba vstoupí na trh práce nejdříve po 22. roce života. Situace by ovšem vypadala jinak, kdyby se jednalo o žáka se spíše podprůměrným prospěchem na základní škole. Po jejím dokončení by zřejmě následovala volba učebního oboru, teoretický vstup na

4 O vztahu lidského organismu a společnosti viz Berger a Luckmann (1999: 177-180). 
pracovní trh by se uskutečnil minimálně o 3 až 4 roky dříve, přičemž je možné, že mezi ukončení školy a skutečný vstup do zaměstnání bude vsunuta fáze nezaměstnanosti. Uvedený př́klad je ovšem velmi zjednodušený, nebot' školní výsledky na základní škole nejsou jedinou proměnnou, která vstupuje do hry. Prostor, v němž se životní běh odvíjí, je totiž mnohovrstevnatý a složitý. K jeho zpřehlednění navrhují Giele a Elder (1998) výše zmíněné rozložení do čtyř dimenzí. Nyní o nich tedy pojednáme zevrubněji.

Umisténí v čase a prostoru (location in time and place) ${ }^{5}$ reprezentuje spolu s dimenzí propojených životů (linked lives) první sociální fakty, ${ }^{6}$ se kterými se jedinec ve svém životě setkává. Tak např́klad k človíčku, který je na světě teprve pět hodin, přichází paní s fotoaparátem (projev historické doby a místa), aby zachytila jeho první okamžiky života a maminka tohoto človička (propojené životy) ho již nabádá, aby se usmíval, nebot' taková je současná kulturní norma fotografování. Další dvě dimenze, lidské jednání (human agency) a načasování (timing), již předpokládají do jisté míry nezávislého aktéra, a tak vstupují do života jedince s určitým zpožděním. Nicméně „pasivni““ forma načasování je přítomna v životě jedince prakticky od počátku. Dřive než je člověk schopen a oprávněn určovat sám načasování významných událostí svého života, stává se běh jeho života objektem strategií jiných osob. Většinou se jedná o osoby, jimž je svěřena péče o něho, nejčastěji tedy o rodiče.

Začněme tedy rozborem dimenze umistěni $v$ čase a prostoru. ${ }^{7}$ Tato dimenze upozorn̆uje výzkumníky na jistý druh setrvačnosti vzorců životních běhů, nebot' „především v rychle se měnících společnostech jsou lidé odlišného roku narození vystaveni různým historickým světům s jejich omezeními a možnostmi““ (Elder 1994: 5).

Zahrnutí vlivu historických okolností na utváření životního běhu zpřesňuje kauzální vysvětlování při jejich analýze. Vliv umístění v čase a prostoru na sebe může vzít podobu periodního či kohortního efektu (Blossfeld a Rohwer 2002). Periodní efekt vzniká důsledkem historické události, která zasáhla životy všech členů dané společnosti, bez ohledu na jejich věk. Zde se jedná např́íklad o přírodní katastrofu, zásadní změnu politického režimu aj. Kohortní efekt se pak týká sociálních změn, které jsou relevantní pouze pro určitou kohortu a na základě kterých se jednotlivé kohorty od sebe významně liší. Může tedy jít o zážitek určité sociální změny, který je typický pro jednu kohortu - např́klad vstup na trh práce v období rychlé restrukturalizace hospodářství. Kohortní efekt může být také způsoben kupříkladu výrazně odlišnou velikostí jednotlivých kohort - např́íklad členové kohorty, v jejímž rámci se odehrál babyboom, mají ztížený přístup $\mathrm{k}$ vyššímu vzdělání a hůře hledají nejen

Je zajímavé, že tyto čtyři dimenze rozvinuli Elder a Giele nezávisle na sobě, přičemž zastávali navzájem opačný pohled na předmět výzkumu. Zatímco Elder se zabýval vlivem historické periody na životní běh jedinců v této době žijících (u zrodu formulace těchto čtyř dimenzí stálo jeho dílo Childern of the Great Depression, 1. vyd. 1974), Giele se zabývala i zpětným vlivem změny životního běhu žen na změnu společnosti (viz Two Path to Woman's Equality, 1995). Jelikož oba vytvořili vlastní názvy pro tyto dimenze, uvádíme obě varianty (na prvním místě Elderův termín a v závorce pojem, jejž navrhla Giele), a to i přesto, že v literatuře převládá Elderova terminologie. Domníváme se totiž, že pojmy Giele přispívají k upřesnění obsahu každé z dimenzí.

6 Ve smyslu společenských jevů, které jsou vzhledem k jedinci vnější a vykonávají na něho tlak.

7 Podle Mayera (2004: 161) právě tato dimenze zohledňující sociální kontext odlišuje teorii životního běhu od konceptů lidského vývoje, biografie a stárnutí. 
Obr. č. 1: Klíčové prvky paradigmatu životního běhu

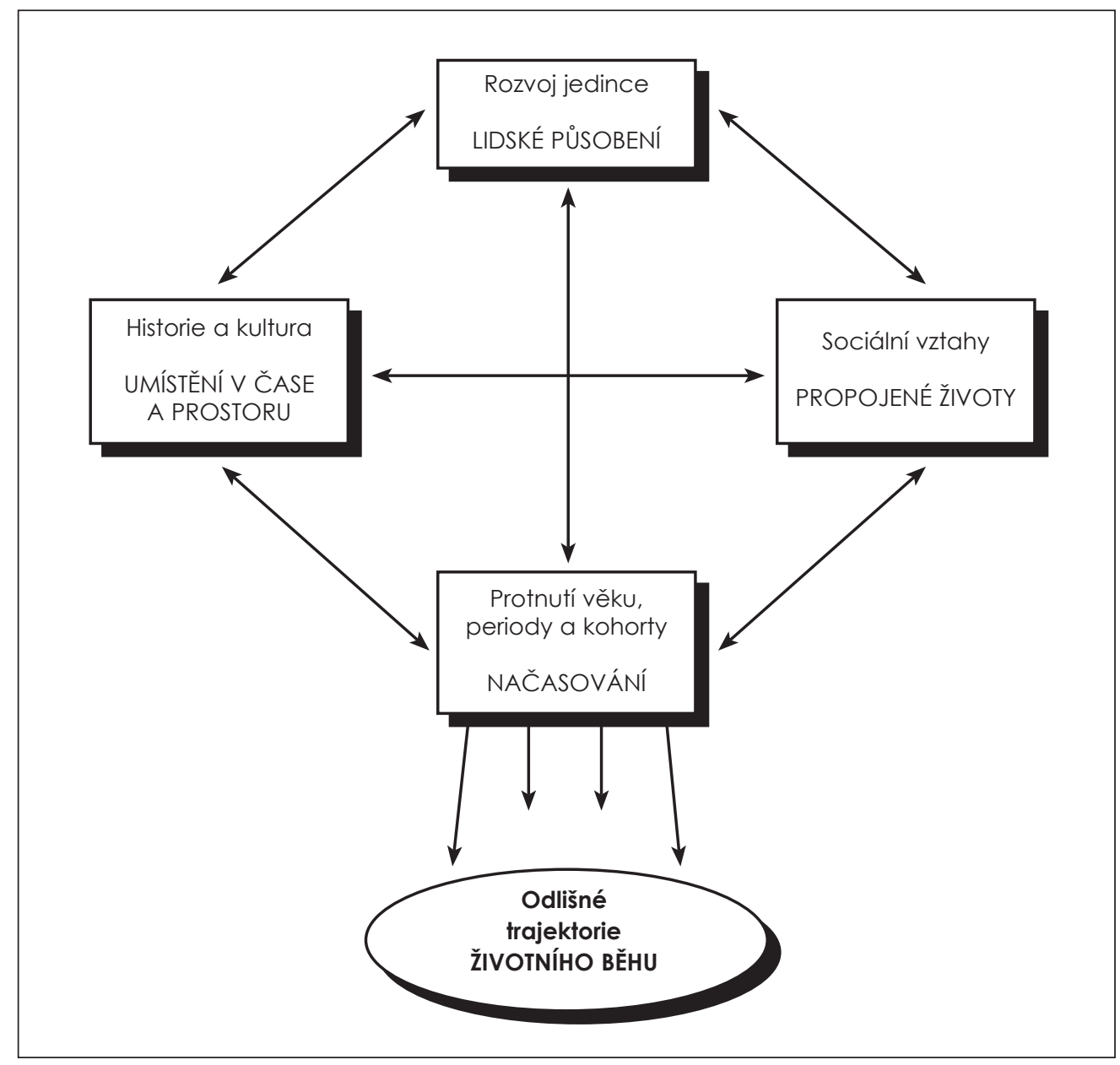

Zdroj: Giele a Elder (1998: 11).

uplatnění na pracovním trhu, ale i životního partnera, v porovnání s předchozí, ale i následující kohortou, nebot' je prostě všude ,přeplněno“.

Umístění v čase a prostoru však neovlivňuje vzorce životního běhu pouze zvnějšku, ve formě struktury př́ležitostí, ale i zevnitř, skrze strukturaci lidského myšlení. Podoba světa, kterou jedinec zakoušel v mládí, je podle Mannheima (1952) určující i pro jeho další život. Rané zážitky vytvářejí „,přirozený obraz světa“ daného jedince. Tímto obrazem pak člověk poměřuje všechny následující zážitky, zkušenosti a události. Historické poměry panující v mládí jedince tak mají rozhodující vliv na jeho další rozhodování a jednání. 
Je zajímavé, že ačkoliv to byla právě Mannheimova esej Otázka generací, která obrátila pozornost sociálních vědců k významu historického času pro utváření odlišných vzorců individuálních životů a stojí tak za začleněním dějinného prvku do paradigmatu životního běhu (Elder 1975), studie vycházející z tohoto paradigmatu s Mannheimovým konceptem generace jako konsturované kolektivní identity většinou nepracují. Domníváme se, že možným vysvětlením je dosavadní tematické zaměření těchto studií, v nichž otázky kolektivních mentalit zůstávají stranou zájmu, a to i přesto, že zvláště evropský výzkum životního běhu často probíhá na bázi kohortního srovnávání.

Nicméně bylo by zavádějící chápat tuto dimenzi jako pouze historickou, ve smyslu nesoučasnou realitu. Naopak umístění $v$ čase a prostoru se týká i aktuální podoby společnosti, již je jedinec členem. Tato dimenze je tak poměrně široká, nebot' zahrnuje jak historický, tak současný sociální kontext: sociální instituce, normy a institucionální uspořádání welfare režimů (Mayer 2004).

Druhá dimenze, propojené životy ${ }^{8}$, reflektuje skutečnost, že lidé jsou tvory sociálními, totiž že nežijí své životy izolovaně, ale v interakci s druhými. Elder (1994: 6) připomíná, že „pro lidské životy je typické, že jsou zakořeněny v sociálních vztazích s př́buznými a přáteli“. Tyto vztahy na jedné straně poskytují jedinci podporu a jsou zdrojem různých typů kapitálu, na straně druhé jsou též nástrojem sociální kontroly a regulace. Důležitý aspekt těchto vztahů představuje vzájemná závislost a ovlivňování. Načasování určitých událostí v životě jedince bývá často ovlivňováno pohybem po životních trajektoriích jiných relevantních osob. Například žena může odkládat své těhotenství na dobu, kdy její partner získá takovou práci, jež zajistí, že se rodina $\mathrm{v}$ důsledku narození dítěte a absence druhého platu nepropadne do chudoby. Samotné narození dítěte pak mění role dalších členů rodiny, a to naprosto nezávisle na jejich vůli $-\mathrm{z}$ matky se stává babička atd.

Tuto dimenzi však netvoří jen př́buzenské vztahy jedince, ale v podstatě všechny vztahy, které jsou součástí jeho každodenní reality. Tedy patř́ sem rovněž spolužáci a učitelé, kolegové $\mathrm{v}$ práci a obchodní partneři, úřednice, která rozhoduje o oprávnění $\mathrm{k}$ pobírání sociálních dávek atd. Ovšem pro aktuální utváření konkrétního životního běhu nemají všechny tyto vztahy současně stejnou relevanci, jejich význam je odstupňovaný a v čase se mění. Tuto dimenzi lze podle Giele (Giele a Elder 1998) ztotožnit s konceptem sociální integrace jedince.

Dimenze třetí, lidské jednání, vychází z teze o povaze dynamických systémů, které aby přetrvaly v čase, musí být schopné naplnit své potřeby. Jelikož člověk mezi tyto systémy bezesporu patří, i on usiluje o naplnění svých potřeb, a to prostřednictvím aktivního rozhodování a jednání (Giele a Elder 1998). Jedinec je vnímán jako aktivní subjekt, který tím, že plánuje a volí mezi možnostmi vymezenými jeho sociálním prostředím, konstruuje svi̊j životní běh. Rozsah a podoba lidského jednáni jedince závisí jednak na interakci biologického, psychologického a sociálního aspektu jeho vývoje (Settersten a Mayer 1997), dále na sociálním kontextu, jako je gender a etnicita (Giele a Elder 1998), a v evropském prostoru i na institucionální regulaci společnosti (Mayer 2004). Ponecháme-li stranou psychologické teorie vztahující se k lidskému jednání, pak v rámci sociologie lze pro bližší porozumění této dimenzi

K obsahu této dimenze možno srovnat i Urie Bronfenbrenner, 1979, Ecology of Human Development, Cambridge: Harvard University Press. 
aplikovat např́klad teorii racionálního jednání nebo východiska symbolického interakcionismu. Clausen (1998) do této dimenze umistuje také koncept identity a procesy integrace self jako možné analytické východisko pro studium životního běhu.

Poslední dimenzí je načasování, které představuje hlavní adaptační mechanismus jedinců. Skrze načasování životních událostí a jejich kombinace v rámci hlavních životních trajektorií - rodina, práce, vzdělávání, volný čas - usiluje jedinec o optimalizaci poměru mezi využitím dostupných zdrojů a minimalizací ztráty či frustrace (Giele a Elder 1998). Nicméně do zvažování nákladů a výhod vstupuje ještě třetí, normativní faktor, a sice generalizovaná očekávání ohledně toho, kdy by se jaká událost měla v životě člověka objevit, neboli věkové normy. Typickým príkladem opět může být plánování založení rodiny, a to zvláště $\mathrm{v}$ životech žen, nebo odkládání vstupu na pracovní trh kvưli „př́liš̌“ dlouhému studiu. Věkové normy nejsou univerzální, ale v různých dobách i společnostech se liší. Marini (1984) však nabádá $\mathrm{k}$ jisté opatrnosti při použivání věkových norem $\mathrm{k}$ vysvětlování lidského jednání. Pomocí věkových norem totiž nelze vysvětlovat vznik a proměny určitých vzorců načasování a seřazení životních událostí v celé populaci, nebot' věkové normy především ztělesňují reflexi vzorců chování, které musí být vysvětleny. Marini však připouští, že na individuální jednání mají věkové normy jistý určující vliv, nicméně nikdy nejde o vliv jediný.

Načasování jako analytická dimenze pak odkazuje jednak k četnosti (incidence), k trvání (duration) a $\mathrm{k}$ posloupnosti (sequencing) přechodů a rolí a dále $\mathrm{k}$ relevantním očekáváním a vírám založených na věku (srov. věkové normy) (Elder 1994, Settersten a Mayer 1997).

Všechny čtyři dimenze životního běhu jsou ve vzájemné interakci, avšak je to právě načasování, skrze které výsledky této interakce vytvárí konkrétní podobu individuálního životního běhu. Proto také načasování poskytuje výzkumníkům výchozí bod či bránu, jíž se vstupuje k okolnostem a mechanismům, které stojí za výslednou podobou životního běhu.

Poté co byl představen způsob, jímž paradigma životního běhu zasazuje život jedince do sociálně-historického kontextu a vymezuje i hlavní aspekty vztahu mezi jedincem a společností, se pokusíme o stanovení obecné definice životního běhu coby konceptu individuálního lidského života. Skrze ni jsou pak v rámci tohoto paradigmatu životy lidí analyzovány a popisovány.

\section{Životní běh jako koncept}

V literatuře a výzkumných zprávách, které vycházejí z paradigmatu životního běhu, narážíme nejen na různá pojetí životního běhu jako konceptu v rámci zmíněných dvou hlavních proudů sociologie životního běhu, evropského a severoamerického, ale i na různost definic stěžejních konceptů tohoto paradigmatu u jednotlivých autorů. Někdy se jejich pojetí liší jen $\mathrm{v}$ detailech, jindy v celkovém pohledu na jev, jenž má koncept zachytit, jindy zas v různé míre akcentu na určité prvky paradigmatu. Tuto skutečnost reflektují i Sackmann s Wingensem (2001). Vnímají ji jako slabou stránku sociologie životního běhu a sami svým př́íspěvkem explicitně usilují o zavedení jednotné terminologie užívané pro popis hlavních prvků životního běhu (sekvence, přechod, trajektorie), nicméně jednotnou definicí životního běhu samého se nezabývají. Existuje-li tedy víceméně konsensus v oblasti pojmů, které tvoří základní stavební kameny konceptu životního běhu (viz níže), pro samotnou definici životního běhu to neplatí. 
Obecně lze říci, že jednotlivé definice konceptu životního běhu popisují jednu a více dimenzí, které v souhrnu odrážejí komplexitu lidského života, již se tento koncept snaží především ze sociální stránky - zachytit.

Někteří autoři definují životní běh primárně z hlediska jeho vlastní struktury. Životní běh jako konceptualizace obecné struktury lidského života je vymezen sociálně definovanou posloupností událostí, jednání, stavů rolí, a přechodů mezi stavy, a to v různých životních doménách, a v neposlední řadě také bodů obratu, které zásadně mění dosavadní směr určité trajektorie (Elder 1975, 1994; Hammer 1996, Mayer 2004). Settersten s Mayerem (1997) dále upřesňují, že hlavní životní trajektorie, které sociologické výzkumy sledují, se týkají vzdělávání, rodiny, práce a blahobytu. Důležitým bodem pro pochopení utváření životního běhu konkrétního jedince je vědomí, že tyto trajektorie jsou propojené a navzájem se ovlivňují (jako klasický př́klad je možno uvést dilema mnoha žen v produktivním věku, spočívající v problému skloubení pracovní kariéry a péče o dítě apod.). Elder (1975, 1994) dodává, že trajektorie jsou věkově odstupňované, tedy že určité události a přechody se typicky vyskytují v souvislosti s určitým chronologickým věkem jedince. Skutečnost, že vstup do školy se očekává v šesti letech a ukončení ekonomické aktivity u mužů v šedesáti dvou letech života, dokládá zásadní vliv určitých sociálních institucí na podobu životního běhu. Nicméně prostor, v němž jedinci utvářejí svůj životní běh, je složitější (viz oddíl Dimenze...).

Další skupina autorů pak při definování konceptu životního běhu akcentuje právě jeho umístění v rámci mnohovrstevnatého prostoru sociální reality. Prostoru, který je na jedné straně vytvářen společností s jejími institucemi, kulturou a historií a na straně druhé jedincem, jeho sociální, psychologickou a biologickou složkou (Giele a Elder 1998). Dominantním předmětem sociologie životního běhu, zvláště evropské tradice, bylo zkoumání vlivu institucionalizovaných systémů na životy lidí a teorie životního běhu se tak soustřed'ovala na vymezení tohoto vztahu. Kromě institucionalizovaných sekvencí pozic a rolí však životní běh formují i kulturní přesvědčení o individuální biografii, právní normy, které se vztahují k věku, a v neposlední řadě též rozhodnutí a jednání individuálních aktérů. Tyto prvky se pak do teorie životního běhu snažili zapracovat kupříkladu Settersten s Mayerem (1997). Dodejme, že tito autoři ještě rozlišují mezi tzv. „objektivní biografií“, která se kryje se způsobem, jímž životní běh utvářejí sociální instituce, a „biografií v užším slova smyslu“, která zdůrazňuje subjektivní interpretaci životního běhu a jeho konstrukci samotným jedincem. Objektivní biografii lze podle našeho názoru ztotožnit s ,institucí životního běhu“ (srov. oddíl Životní běh jako instituce).

Od spíše nejednoznačně vymezeného konceptu životního běhu přejděme nyní k dílčím analytickým pojmům, s jejichž pomocí sociální vědci zkoumají a popisují instituce životního běhu a usilují o jejich vysvětlení.

Klíčovými koncepty jsou událost (life event), přechod (transition) a trajektorie. Ačkoliv událost i přechod odkazují ke změnám ve stavu, což je obvykle změnitelná pozice zastávaná v životním běhu, jako např́íklad „svobodný“, „,nezaměstnaný“, „otec“ aj. (Sackmann a Wingens 2003), událost ${ }^{9}$ představuje relativně prudkou změnu, např́iklad ,úrredně rozveden“

Zvláštním typem události jsou body obratu; více viz např́íklad Sackamnn a Wingens (2001: 26-27). 
$\mathrm{k}$ určitému datu. Naopak přechod reprezentuje změnu postupnou, proces. V tomto smyslu by byl rozvod analyzován jako sled událostí a dílčích rozhodnutí vedoucích ke zrušení manželství. Přechody se vždy uskutečňují v rámci trajektorie, „která jim dává konkrétní formu a význam“ (Elder 1994: 5). Nelze je tedy studovat izolovaně od kontextu dané trajektorie.

Zatímco přechod již byl relativně jasně definován a není obtížné ho operacionalizovat, koncept trajektorie zůstává termínem poněkud vágním. Podle Eldera (1985: 31) lze trajektorii vymezit „procesem stárnutí nebo pohybem skrze věkovou strukturu“. Settersten s Mayerem (1997: 252) upřesňují, že „trajektorie jsou vyznačeny sledem po sobě následujících událostí a přechodů“. Životní běh každého jedince si pak můžeme představit jako jakýsi nepravidelný propletenec různých, vzájemně souvisejících trajektorií (např́íklad pracovní, rodinné a vzdělávací trajektorie). Mayer (1990: 11, citováno dle Sackmann a Wingens 2001: 21) dodává, že při zkoumání přechodů, událostí a životních fází je třeba brát v úvahu nejen mnohonásobné trajektorie, ale i „okolnosti, rozhodnutí, zdroje a zkušenosti, které se objevily v životní historii, která předcházela aktuálně zkoumanému přechodu“ (srov. dynamický princip výše).

Settersten s Mayerem (1997) uvádějí ještě další koncepty, kterých se často užívá právě k popsání životních událostí a přechodů. U životních přechodů se studuje i jejich načasování, posloupnost (sequencing), trvání (duration) a odstup (spacing). Avšak zatímco s koncepty načasování (věk, v němž se daný přechod v rámci životního běhu uskuteční) a posloupnosti (sled či pořadí, v němž jsou přechody jedincem zaživány) pracují i kvalitativní studie, termíny trvání (jako doba strávená v určitém stavu) a odstup (doba mezi dvěma či více přechody) jsou typické pro longitudinální kvantitativní analýzu životních událostí (event history analysis). Uvedené koncepty jsou specifické pro paradigma životního běhu a vymezují odlišnost jeho př́stupu vůči studiu přechodů v rámci teorie sociálních rolí.

Studium individuálních životů pomocí konceptu životního běhu odhalilo socio-kulturně podmíněné pravidelnosti v podobách a průběhu lidských životů v moderních společnostech. Na jeho základě byly identifikovány typické vzorce individuálního životního běhu. Jak ukážeme vzápětí, tyto vzorce mají pro jedince i společnost zásadní význam.

\section{Životní běh jako instituce}

Kohli (1985) patrně poprvé formuloval požadavek chápat životní běh jako sociální fakt, který je součástí sociální struktury. Kohli upřesňuje, že životní běh je vlastně sociální institucí, nebot' „normativni““ či „normální“ životní běh, který identifikoval a popsal, reprezentuje sociálně sdílenou a očekávanou kombinaci statusů a rolí. Tato očekávání souvisejí s věkem jedince a působí rovněž jako sociální kontrola (srov. objektivní biografie výše).

Současná podoba instituce životního běhu je, jak naznačujeme dále, předmětem zkoumání s často rozpornými závěry. O jeho aktuálně platné definici se vedou rozsáhlé diskuse. Referenční bod těchto studií a diskusí představuje právě zmiňovaný normativní životní běh popsaný Kohlim. Pro jejich pochopení je tedy nutná jistá obeznámenost s tímto modelem životního běhu - nejen s jeho vymezením, ale i s genezí jeho vzniku, která velmi úzce souvisí s rozvojem moderní společnosti, nebot' podoba společnosti z velké míry určuje instituci životního běhu. 
V následujícím textu se proto věnujeme nejprve společenským podmínkám vzniku tzv. „normativního“ životního běhu a také jeho definování. Poté předložíme kritiku tohoto konceptu a pojednáme o jeho modifikované alternativě, o „post-industriálním“ životním běhu.

\section{Historické okolnosti vynoření se normativního modelu životního běhu}

Jak již bylo uvedeno výše, institucionalizovaný životní běh lze vnímat jako produkt určitých historických okolností, nebo přesněji jako společenskou a individuální reakci na zásadní historické změny, které provázely přeměnu tradiční společnosti v moderní. Pojd’me se tedy nyní blíže podívat na to, které z těchto změn považoval Kohli (1985) za zásadní pro vynoření se normativního životního běhu a proč:

První a nutnou podmínkou jeho vzniku a rozvoje bylo výrazné zvýšeni naděje na dožití obyvatel, a to právě v důsledku modernizačních procesů. Zatímco v USA přibližně $30 \%$ dětí narozených $\mathrm{v}$ roce 1840 nemělo naději se dožít ani deseti let a jen polovina této kohorty dosáhla více než padesáti let, $\mathrm{v}$ roce 1980 se riziko úmrtí před 50. rokem věku týká asi jen $5 \%$ dané kohorty, přičemž tři čtvrtiny mají naději, že se dožijí alespoň 75 let. Tento demografický vývoj umožnil přechod od koncepce života jako náhodného a nepředvídatelného sledu událostí $\mathrm{k}$ předvídatelnému, a tedy i plánovatelnému modelu. Nicméně samotné zvýšení naděje na dožití není dostačující podmínkou vzniku normativního modelu životního běhu.

Dalši strukturální změnu, která se na jeho konstituci podílela, představuje proměna rodinného cyklu. Díky značné proměnlivosti rozsahu př́buzenstva a jeho věkového složení, právě v důsledku vysoké úmrtnosti, lze v předmoderní době stěží užívat pojem rodinný cyklus. Naopak pro dobu moderní je standardizovaný rodinný cyklus charakteristický. Rodinný cyklus, který probíhá jako sled chronologicky po sobě jdoucích, předem definovaných rodinných událostí, přispívá i k chronologické standardizaci individuální biografie.

Třetí historickou okolností, která přispěla a přispívá k rozvoji chronologického a standardizovaného životního běhu jedinců, je povaha právního systému modernich států a př́tomnost institucionálního sociálního zabezpečení obyvatel. Věkově stratifikovaný systém práv a povinností (například věková hranice zahájení povinné školní docházky, právní zodpovědnosti atd.) a systémy sociálního zabezpečení (především školský a důchodový systém) jsou původci vydělení hlavních fází života vymezených věkovými hranicemi (mládí, dospělost, stáŕí), na jejichž základě Kohli (1985) vytvořil svůj trojdílný normativní model životního běhu (viz dále).

Posledni okolností, která završuje konstituování moderního životního běhu, je individuální zvnitřnění jeho chronologického a standardizovaného modelu. Kohli odkazuje na proměnu biografické perspektivy, jak ji ve svých dílech popisují jednak Norbert Elias a Michel Foucault $\mathrm{v}$ termínech internalizované sebekontroly a vnitřního tlaku ve směru k dlouhodobému plánování a na něm založenému jednání, jednak Peter L. Berger, podle něhož se dlouhodobé plánování v podobě životních projektů stalo i „primárním zdrojem identity“ a „základním organizačním principem“.

Uvedená Kohliho (1985) analýza strukturálních proměn společnosti osvětluje přitomnost prvků chronologizace a standardizace v moderním životním běhu jako důsledek procesů modernizace, avšak fakt, že moderní životní běh je koncipován jako ryze individuální, 
ponechává poněkud stranou. Touto otázkou se později zabývají Mayer s Müllerem (1989) a odpovídají na ni tezemi o souvislosti mezi vývojem moderního národního a sociálního státu a vynořením se individuálního životního běhu.

Moderní stát skrze princip občanství přesouvá práva a povinnosti z kolektivních aktérů (rodina, město, klášter, farnost) na individuální subjekt. Započatou individualizaci života pak dále posiluje uznání sociálních práv jako nedílné součásti statusu občana. Institucionální zajištění těchto práv je nastaveno tak, že postupně uvolňuje jedince ze závislosti na jeho bezprostředním sociálním okolí a $\mathrm{z}$ velké míry ho vyvazuje i z př́mé zodpovědnosti za zajištění sociálních potřeb blízkých osob v situaci, kdy toho nejsou samy schopny (nemoc, stáří). Kromě ústřední role moderního státu při vynoření se individuálního subjektu jako základního prvku sociální struktury spatřují Mayer s Müllerem druhou paralelu mezi rozvojem moderního státu a ustavením individuálního životního běhu v průmětu celospolečenského procesu diferenciace (zvláště faktů rozštěpení domácnosti a výroby a funkcionální dělby práce mezi rodinou a školou) do struktur životního běhu. Jedinec se v průběhu života stává nositelem nikoliv nahodilého sledu sociálních rolí, které se mění nejen v závislosti na sociálním prostředí, v němž se právě nachází (např́klad strýc a člen domovní samosprávy), ale i vzhledem k fázi životního běhu (student, podnikatel, důchodce aj.). Tyto role jsou však navzájem oddělené.

Můžeme tedy shrnout, že institucionalizovaný životní běh se stal součástí sociální reality jednak díky určitým historickým okolnostem, které provázely proměnu tradiční společnosti v moderní, a dále díky dalšímu rozvoji moderního národního a sociálního státu. Výslednou podobu takto ustaveného životního běhu lze charakterizovat termíny chronologizace, standardizace, institucionalizace, individualizace a segmentace.

Obr. č. 2: Proměna předmoderního životního běhu v moderní

\begin{tabular}{|c|c|c|}
\hline $\begin{array}{l}\text { Kategorizace } \\
\text { (mladý/starý, otec/syn) }\end{array}$ & $\longrightarrow$ & $\begin{array}{l}\text { Časovost } \\
\text { (zcela nová dimenze } \\
\text { životního běhu) }\end{array}$ \\
\hline $\begin{array}{l}\text { Funkčnost } \\
\text { (převzetí farmy, hladomory, } \\
\text { smrtelné úrazy) }\end{array}$ & $\begin{array}{l}\longrightarrow \\
\longrightarrow\end{array}$ & $\begin{array}{l}\text { Chronologizace } \\
\text { (standardizované } \\
\text { normální životní běhy) } \\
\text { Individualizce } \\
\text { (více možností volby) } \\
\text { Organizováno kolem } \\
\text { zaměstnaneckého } \\
\text { systému }\end{array}$ \\
\hline & $\longrightarrow$ & $\begin{array}{l}\text { Dvě roviny jednání: } \\
\text { souslednost pozic } \\
\text { a biografická perspektiva }\end{array}$ \\
\hline
\end{tabular}

Sestaveno dle Kohli (1985). 


\section{Normativní model životního běhu}

Jak vypadal životní běh, který byl výsledkem výše uvedených historických změn? Na následujících řádcích představujeme dnes již klasický Kohliho (1985) model moderního institucionalizovaného průběhu života - „,normativní životní běh“.

Kohliho přístup ke studiu a konstrukci normativního modelu životního běhu se velmi blíží perspektivě strukturního funkcionalismu. Životní běh chápe jako svébytnou dimenzi společenské struktury, která je jednak ,generována zvláštním systémem pravidel“, jednak má povahu sociální instituce, ,,ve smyslu systému pravidel, který reguluje určitou centrální oblast či dimenzi života“ (Kohli 1985: 1). Životní běh je tedy na jedné straně produktem určitých společenských podmínek (viz výše), na straně druhé sám sociální realitu vytváří, reprodukuje a mění, a to jak skrze usměrňování individuálních životů, tak skrze potenciál jedinců svůj život, a tedy i vzorce životního běhu, aktivně utvářet (srov. např. Giele, Elder 1998). Posledně zmíněná poznámka však již přesahuje Kohliho úhel pohledu. Kohli analyzuje tuto instituci takříkajíc „,z venku“ - jako sociální fakt, který určitým způsobem vznikl, má jistou podobu a plní specifickou společenskou funkci. Ačkoliv Kohli připouští, že životní běh představuje nejen institucionální program, ale je i subjektivní konstrukcí, nebot' je konkretizován a spoluutvářen také jednáním individuálních aktérů, rozměr lidského jednání se v jeho konstrukci normativního modelu téměř neprojevil.

Jako instituce působí normativní životní běh podle Kohliho na dvou rovinách - tak ř́kajíc ,Zvenčí“ a ,zevnitřr“. „Zvenku“, prostřednictvím státních opatření (systém zákonných práv a povinností a také systém oprávnění vztahujících se k sociálnímu zabezpečení), reguluje normativní životní běh načasování a posloupnost stádií a přechodů, kterými člověk prochází. Stejně tak působí ,zevnitř̌“, nebot' rovněž reprezentuje ,strukturaci horizontů životního světa, respektive zásoby vědění, v jejímž rámci se jedinci orientují a plánují své jednání“ (Kohli 1985: 3). Skrze individuální zvnitřnění normativních požadavků životního běhu tato instituce ovlivňuje jak sebepojetí jedince, tak jeho jednání a cíle. Kohli věnuje většinu své pozornosti společenské funkci institucionalizovaného životního běhu. Tou je odpověd' na zásadní problémy každé společnosti, a sice na problém racionalizace, sociální kontroly, sukcese a integrace. Nicméně reflektuje i antropologický rozměr ${ }^{10}$ této instituce, když poukazuje na její dvojsečný význam pro život jedince. Na jedné straně institucionalizovaný životní běh poskytuje lidem v moderní době „,nutné odlehčení“ v rozhodování o utváření vlastního života v podmínkách širokých možností volby, které modernita předkládá, a to tím, že „dává průběhu života pevnou kostru a stanovuje kritéria toho, co je a co není dosažitelné“, současně však také „znamená omezení individuálního prostoru jednání“ (Kohli 1985: 19-20).

Normativní životní běh je dále podle Kohliho standardizován, a to právě primárně skrze onu státní regulaci, která platí pro všechny občany určitých věkových skupin stejně. Standardizace životního běhu tedy úzce souvisí s jeho institucionalizací. Kohli patrně standardizací odkazuje ke třem stádiím svého normativního modelu a k přechodům mezi nimi. Většina lidí prochází těmito stádií $\mathrm{v}$ předem daném pořadí a přechody $\mathrm{v}$ definované podobě ${ }^{11}$ uskutečňuje přibližně ve stejném věku.

\footnotetext{
10 Více o funkcionálním a antropologickém pojetí instituce viz Keller (1995: 55-56).

11 Např́klad že přechod do dospělosti se skládá z následujících událostí, které jdou v krátkém časo-
} 
Právě sepětí standardizovaného průběhu života jedince s jeho biologickým věkem představuje třetí typickou vlastnost normativního modelu životního běhu, kterou je chronologizace.

Jak tedy normativní model životního běhu vypadá?

Obr. č. 3: Normativní model životního běhu

\begin{tabular}{|c|c|c|c|c|}
\hline Vzdělání & $\stackrel{\longrightarrow}{\text { přechod }}$ & Zaměstnání & $\overrightarrow{\text { přechod }}$ & Starobní důchod \\
\hline
\end{tabular}

Jeho centrálním prvkem je ekonomická aktivita jedince: „Životní běh je v moderních společnostech organizován kolem systému výdělečné činnosti. To platí jak pro vnější podobu životního běhu - nejnápadnější časové dělení dnes představuje třífázový životní běh: přípravná, aktivní a odpočinková fáze (dětství/mládí, ekonomicky aktivní život, stáří); tak pro jeho základní organizační princip“" (Kohli 1985: 3).

Shrňme tedy nyní krátce a stručně Kohliho pojetí moderního životního běhu: považuje ho za institucionalizovanou, standardizovanou a s chronologickým věkem související sociální skutečnost, která se skládá ze tří hlavních fází - vzdělávání, ekonomické aktivity, starobního důchodu; jeho osou je formalizovaná výdělečná činnost; představuje moderní řešení problémů spojených s přežitím a reprodukcí společnosti.

\section{Kritika normativního životního běhu}

Kohli (1985) nevnímal normativní životní běh jako model života, který by byl univerzálně platný např́íč časem a prostorem. Naopak, snažil se ukázat, jak vynoření se moderního životního běhu souvisí s určitými historickými (hospodářskými a společenskými) podmínkami (viz oddíl Historické...). Lze tedy předpokládat, že změny těchto podmínek přinesou i změnu individuálního životního běhu a že tuto změnu budou dále reflektovat i sociální vědy v diskusích o platnosti původního pojetí životního běhu, v jeho revizi a v úsilí o jeho nové vymezení.

Než se ale budeme věnovat možným proměnám instituce životního běhu v důsledku proměny společnosti, jak je diskutují vybraní autoři, chceme upozornit na jedno významné omezení Kohliho modelu, které tento model provází od jeho formulování. Jak je uvedeno v předchozím oddíle, $v$ rámci normativního životního běhu postupuje jedinec uvedenými fázemi (viz Obr. 2) poměrně neproblematicky vpřed - nejprve dokončí přípravu na povolání, pak je vykonává a posléze odchází na zasloužený odpočinek. Nicméně tento model byl i v době, kdy Kohli uveřejnil svou stat', platný pouze pro část obyvatel moderních společností, a sice

vém sledu za sebou, a sice vedle opuštění původní rodiny a sňatku k těmto událostem náleží také ukončení formálního školního vzdělávání, přijetí pravidelné výdělečné činnosti a založení vlastní domácnosti (Modell, Furstenberg a Hershberg 1976). 
především pro muže. Životní běh žen naprosto uvedenému modelu neodpovídal, nebot' byl silněji svázán s rodinným cyklem než s pracovním trhem (více viz např́ílad Maier 1997).

Další kritické argumenty vůči normativnímu modelu životního běhu již vycházejí z tezí o současných proměnách moderní společnosti. Klíčovými změnami, které mají výrazný dopad na insitituci životního běhu, jsou demografické a ekonomické trendy, globalizace, proměna postavení placené práce ve společnosti, proměny pracovních vztahů a trhu práce vůbec - zejména fragmentované pracovní kariéry, celoživotní vzdělávání, rozostřené přechody (viz např́íklad Beck 2004, Chisholm 2006, Mortimer a Larson 2002, Wyn a Dwyer 2000).

V současné době je rozsáhle diskutována především validita Kohliho (1985) trojdílného členění životního běhu - mládí, dospělost a stáří - $\mathrm{s}$ dvěma hlavními přechody - do dospělosti a do stárí. Od 70. let 20. století je v post-industriálních společnostech (Arnett 2000, du Bois-Reymond a Chisholm 2006, Bynner 2005, Guillemard 1991, Mortimer a Larson 2002) $\mathrm{s}$ rostoucí intenzitou pozorováno časové rozvolnění obou přechodů a destandardardizace posloupnosti dílčích kroků vedoucích $\mathrm{k}$ dospělosti či ke statusu důchodce. Tyto přechody nově zahrnují i možnost zpětných kroků. Od 90 . let je podobný vývoj pozvolna pozorován i u nás (Macek 2005). Zvláště proměnám postupu po rodinné trajektorii se již věnovala řada studií (viz např́ílad Možný 2002, Rabušic 2001, Rychtaříková 2006, Sobotka 2006, Zeman 2006). Tento vývoj pak klade otazníky nejen nad konstrukcí přechodů, ale i nad vymezením zmíněných tří fází. Například co se týče mládí a dospělosti hovoří někteří o prodlužujícím se mládí (např́klad Bynner 2006, Fussell 2002), jiní zastávají názor, že se naopak prodlužuje dospělost, nebot' některé její znaky nastupují v dřívějším věku jedince (Wyn a Dwyer 2000). Další jsou přesvědčeni, že mezi mládí a dospělost byla vsunuta nová životní fáze - „vynořující se dospělosti“ (Arnett 2000, Galland 1995) a ještě jiní se ptají, jak vůbec dospělost v současné době definovat (Blatterer 2005, Gil Calvo 2005).

Pro ilustraci rozsáhlých diskusí na téma proměn instituce životního běhu byly vybrány dvě studie z let devadesátých zabývající se přechody do fáze stáŕí a dospělosti.

Guillemard (1991) provedla srovnávací analýzu přechodu z ekonomicky aktivního života do starobního důchodu v šesti zemích. Došla k závěru, že Kohliho (1985) propozice normativního životního běhu, který je v rostoucí míre standardizován prostřednictvím chronologických věkových hranic, už neodpovídá sociální realitě moderních společností. Zaprvé dochází ke všeobecnému zkracování ekonomicky aktivní části života, a to díky delšímu období vzdělávání a časnějším odchodům do důchodu. Dále Guillemard na základě vlastních analýz konstatovala zánik ,standardního životního běhu“.

$\mathrm{K}$ tomuto závěru ji přivedly dva indikátory. Jednak pozorovala erozi standardizované věkové hranice pro odchod do důchodu. Zákonem stanovený důchodový věk byl významně modifikován subsystémy sociálního státu (především pojištěním pro případ nezaměstnanosti a invalidity), takže mnozí lidé se stávali starobními důchodci fakticky mnohem dříve, než dosáhli zákonného věku pro odchod do důchodu, a sice díky bud' dlouhodobé nezaměstnanosti, nebo díky nemoci. Tento jev Guillemard označuje jako „stezky předčasných důchodü“ (Frühverrentungspfade). Nicméně rozostření přechodu do starobního důchodu pozorovala i po dosažení zákonného důchodového věku. Zjistila, že status starobního důchodce není definitivní, totiž že lidé, kteř́ odešli do důchodu v souladu se zákonnou normou, se často krátkodobě na trh práce vracejí. V této souvislosti mluví Guillemard o „fragmentovaném 
procesu odchodu do důchodu“. Třetí argument, kterým Guillemard podpírá tezi o zániku normativního životního běhu, jak ho definoval Kohli (1985), je závěr poukazující na rostoucí význam funkčního věku pro strukturování určitých životních událostí, a to na úkor věku chronologického, jak je možno vyčíst z prríkladu předčasných a pracujících důchodců. Guillemard tak zpochybnila standardizaci a chronologizaci čśsti současného životního běhu.

Erozí normativního životního běhu se zabýval rovněž Mayer (1995), nezkoumal však odchod do důchodu, ale soustředil se na první z přechodů, čili na přechod ze školy do zaměstanání či obecně na pracovní trh. Mayer provedl srovnání šesti kohort podle roku narození (od roku 1920 do roku 1960) pocházejících ze spolkových zemí dřívějšího SRN a čtyř kohort $\mathrm{z}$ bývalých východoněmeckých zemí. Dospěl k překvapivému závěru, že totiž stabilita přechodových vzorců $\mathrm{v}$ životním běhu je relativně vysoká, respektive že proměna je velmi pozvolná. Ačkoliv existuje řada jednoznačných trendů (např́ílad prodloužená doba, kterou ženy stráví ve vzdělávacím systému), přesto se tyto trendy týkají jen malého podílu obyvatel, a proto nelze hovořit o novém univerzálním modelu životního běhu. Mayer na základě uvedených závěrů spíše vyjadřuje podporu přetrvávání standardizovaného a institucionalizovaného modelu životního běhu, než že by ho popíral.

Uvedené studie reprezentují podobu a nejednotnost současných diskusí o proměnách instituce životního běhu, kdy se na jedné straně hovoří o destandardizaci a deinstitucionalizaci životního běhu (Guillemard 1991, Han a Moen 1999, Shanahan 2000), na straně druhé o sílící institucionalizaci (Kohli 1985, Leisering 2003, Mayer 1995). Jak je možné, že sociální vědci docházejí k tak odlišným výsledkům? Ponecháme-li stranou př́padná pochybení při sběru a analýze dat, pak se nabízejí dvě možná vysvětlení - dlouhodobost rozvoje trendů a komplexita procesu vývoje životního běhu. Zatímco Kohli (1985) je spíše pesimistou ohledně možnosti odlišení dlouhodobých vývojových trendů v oblasti životního běhu od krátkodobých variancí v posledních patnácti letech výzkumu, Mayer (1995) je přesvědčen o tom, že př́icinou zdánlivě naprosto protichůdných závěrů ohledně podoby současného životního běhu je badateli podceněná vysoká komplexita procesů proměny životního běhu v moderních průmyslových společnostech (srov. oddíl Dimenze...). Týž proces se tak může z různých úhlů pohledu jevit dosti odlišně. Je tedy nutný další výzkum, který by již tuto komplexitu zohledňoval. Mayer zároveň dodává, že popisy životního běhu v termínech, jako je destandardizace, jsou jednostranné a postulované komplexitě zkoumaného jevu nevyhovují.

\section{Závěr}

Paradigma životního běhu představuje jeden z možných př́stupů sociálních věd ke studiu každodenního života lidí v moderních společnostech. Zohledňuje jak jeho dynamiku, tak jeho mnohovrstevnatost a také počítá s komplexitou vztahů a sítí, v nichž je individuální život usazen a které rovněž ovlivňují jeho výslednou podobu. Stejně jako žitý život zpětně ovlivňuje je.

S trochou nadsázky bychom mohli říci, že jde nejen o možný, nýbrž i o moderní výzkumný prístup, nebot' svou multidimenzionalitou a propojením mikro- a makroúrovně sociální reality obsahuje velký potenciál pro interdisciplinární spolupráci různých sociálněvědných oborů, zvláště pak sociologie, psychologie, ekonomie, ale i sociální práce. Dále pak 
také usmiřuje dlouholeté spory mezi zastánci kvalitativního a kvantitativního výzkumného designu tím, že často využívá kombinaci obého.

Záměrem této stati bylo představit české odborné veřejnosti základní konceptuální východiska teorie životního běhu a poskytnout vodítko pro orientaci v množství odborných textů, převážně zahraniční provenience, které se tomuto tématu věnují.

Uvedené vymezení teoretických variací na téma životní běh, tj. životní běh jako paradigma, analytický koncept a instituce, však nelze považovat za konečné. Rozvoj paradigmatu životního běhu totiž stále pokračuje. Zčásti díky nárůstu možností při zpracování biografických dat (viz např́klad Blossfeld a Rohwer 2002), zejména pak v reakci na současné proměny individuálních životů. Tyto svým vývojem přinášejí nové otázky a výzvy adresované všem třem teoretickým formám tohoto pojmu. Zvláště aktuální otázkou se stává vztah mezi individualizací, standardizací a institucionalizací individuálního životního běhu. Končí éra životního běhu jako instituce (viz Guillemard 1995, Shanahan 2000)? A přstává tak být koncept životního běhu vhodným analytickým nástrojem a teorie životního běhu ztrácí svou explanační sílu, o překonání paradigmatu ani nemluvě? Nebo naopak není žádný důvod k panice, nebot' jsme svědky postupující a nové institucionalizace životního běhu, jak argumentují např́klad Beck (2004) a Leisering (2003)? Či snad dokonce životní běh představuje výzvu a šanci adekvátně uchopit rapidní proměny post-industriálních společností (Heinz a Krüger 2001)?

To však jsou již otázky překračující záměr této statě. Pro tuto chvíli se autorka loučí s konstatováním, že koncept, paradigma a instituce životního běhu prokazují schopnost zaznamenat současné proměny životního běhu, i když přesnější určení a vysvětlení těchto proměn je dosud předmětem výzkumu a diskuse.

\section{Literatura}

Alan, J. 1989. Etapy života očima sociologie. Praha: Panorama.

Arnett, J. J. 2000. „Emerging Adulthood: A Theory of Development From the Late Teens Through the Twenties." American Psychologist, 55 (5): 469-480.

Arnett, J. J. 2006. „Emerging Adulthood in Europe: A Response to Bynner.” Journal of Youth Studies, 9 (1): 111-123.

Beck, U. 2004. Riziková společnost: Na cestě k jiné moderně. Praha: Slon.

Berger, P. L.; Luckmann, T. 1999. Sociálni konstrukce reality. Brno: CDK.

Blatterer, H. 2005. „New Adultdhood: Personal or Social Transition?“ Paper presented to the Social Change in the $21^{s t}$ Conference, Centre for Social Change Research, Queensland University of Technology, 28 October 2005.

Blossfeld, H. P.; Rohwer, G. 2002. Techniques of Event History Modeling: New Approaches to Causal Analysis. London: Lawrence Erlbaum Associates.

du Bois-Reymond, M.; Chisholm, L. 2006. „Young Europeans in a Changing World.“ New Directions for Child and Adolescent Development, Fall 2006, No. 113, s. 1-9. [cit. 14. 3. 2007]. Dostupný z: http://www.interscience.wiley.com

Bynner, J. 2006. „Rethinking the Youth Phase of the Life-Course: The Case for Emerging Adulthood?" Journal of Youth Studies, 8 (4): 367-384. 
Cain, L. D., Jr. 1964. „Life Course and Social Structure.“ In R.E.L. Faris (ed.) Handbook of Modern Sociology. Chicago: Rand McNally, s. 272-309.

Clausen, J. A. 1998. „Life Reviews and Life Stories.“ In J. Z. Giele, G. H. Elder Jr. (eds.) Methods of Life Course Research: Qualitative and Quantitative Approaches. London: SAGE, s. 189-212.

Elder, G. H., Jr. 1975. „Age Differentiation and the Life Course.“ Annual Review of Sociology, 1: 165-190.

Elder, G. H. Jr. 1985. „Perspectives on the Life Course“. In G. H. Elder Jr. (ed.) Life Course Dynamics. Trajectories and Transitions, 1968-1980. Ithaca: Cornell University Press, s. $23-49$.

Elder, G. H., Jr. 1994. „Time, Human Agency, and Social Change: Perspectives on the Life Course." Social Psychology Quarterly, 57 (1): 4-15.

Elder, G. H., Jr. 1995. „The Life Course Paradigm: Social Change and Individual Development.“ In P. Moen, G. H. Elder Jr., K. Lüscher (eds.) Examining Lives in Context: Perspectives on the Ecology of Human Development. Washington: APA Press, s. 101-139.

Fussell, E. 2002. „Youth in Aging Societies.“ In J. T. Mortimer, R. W. Larson (eds.) The Changing Adolescent Experience: Societal Trends and the Transition to Adulthood. Cambridge: Cambridge University Press, s. 18-51.

Galland, O. 1995. „What is Youth?“ In A. Cavalli, O. Galand (eds.) Youth in Europe. London: Pinter, s. 1-6.

Giele, J. Z.; Elder, G. H. Jr. 1998. „Life Course Research: Development of a Field“ In J. Z. Giele, G. H. Elder Jr. (eds.) Methods of Life Course Research: Qualitative and Quantitative Approaches. London: SAGE, s. 5-27.

Gil Calvo, E. 2005. „The Aging of the Young“. Youth Studies Magazine: Autonomy of the Young in Europe. Dec. 2005, No. 71, s. 9-17.

Guillemard, A. M. 1991. „Destandardisierung des Lebenslaufs in den europäischen Wohlfahrtsstaaten." Zeitschrift für Sozialreform, 37: 620-239.

Hammer, T. 1996. „Consequencies of Unemployment in the Transition from Youth to Adulthood in a Life Course Perspective." Youth and Society, 27 (4): 450-468.

Han, S. K.; Moen, P. 1999. „,Clocking Out: Temporal Patterning of Retirement.“ The American Journal of Sociology, 105 (1): 191-236.

Heinz, R. W. 2003. „Combining Methods in Life-Course Research: A Mixed Blessing?“ In R. W. Heinz, V. W. Marshall (eds.) Social Dynamics of the Life Course. New York: Aldine de Gruyter, s. 73-90.

Heinz, R. W.; Krüger, H. 2001. „Life Course: Innovations and Challenges for Social Research.“ Current Sociology, 49 (2): 29-45.

Chisholm, L. 2006. „European Youth Research: Development, Debates, Demands.” New Directions for Child and Adolescent Development, Fall 2006, No. 113, s. 11-21. [cit. 14. 3. 2007]. Dostupný z: http://www.interscience.wiley.com

Keller, J. 1995. Úvod do sociologie. Praha: SLON.

Klein, D. M.; White, J. M. 1996. Family Theories: Introduction. London: Sage.

Kohli, M. 1985. „Die Institutionalisierung des Lebenslaufs. Historische Befunde und Theoretische Argumente.“ Kölner Zeitschrift für Soziologie und Sozialpsychologie, 37: 1-29. 
Leisering, L. 2003. „Government and the Life Course.“ In J.T. Mortimer, M. J. Shanahan (eds.). Handbook of the Life Course. New York: Kluwer, s. 205-227.

Macek, P. 2005. „Kde končí dospívání a kde začíná dospělost?“ In P. Macek, J. Dalajka (eds.) Vývoj a utvárení osobnosti v sociálních a etnických kontextech. Brno: Masarykova universita v Brně, s. 217-225.

Marshall, V. W.; Mueller, M. M. 2003. „Theoretical Roots of the Life-Course Perspective.“ In W. R. Heinz, V. W. Marshall (eds.) Social Dynamics of the Life Course. New York: Aldine de Gruyter, s. 3-32.

Maier, F. 1997. „Entwicklung der Frauenerwerbstätigkeit in der Europäischen Union.“ Politik und Zeitgeschichte, B52/1997, s. 15-27.

Mannheim, K. 1952. „The Problem of Generation.“ In K.Mannheim Essays on the Sociology of Knowledge. London: Routledge \& Kegan Paul, s. 276-320.

Marini, M. M. 1984. „Age and Sequencing Norms in the Transition to Adulthood.“ Social Forces, 63 (1):229-244.

Mayer, K. U. 1995. „Gesellschaftlicher Wandel, Kohortenungleichheit und Lebensverläufe.“ In P. A. Berger, P. Sopp (Hrsg.) Sozialstruktur und Lebenslauf. Opladen: Leske+Budrich, s. $27-47$.

Mayer, K. U. 2004. „Whose Lives? How History, Societies and Institutions Define and Shape Life Course." Research in Human Development, 1 (3): 161-187.

Modell, J. F.; Furstenberg F. Jr.; Hershberg, T. 1976. „Social Change and Transitions to Adulthood in Historical Perspektive." Journal of Family History, 1 (1): 7-32.

Mortimer, J. T.; Larson, R. W. (eds.) 2002. The Changing Adolescent Experience: Societal Trends and the Transition to Adulthood. Cambridge: Cambridge University Press.

Možný, I. 2002. Česká společnost: Nejdůležitějši fakta o kvalitě našeho života. Praha: Portál.

Rabušic, L. 2001. „Value Change and Demographic Behaviour in the Czech Republic.” Czech Sociological Review, 9 (1): 99-122.

Riley, M. W.; Johnson; M.; Foner, A. (eds.). 1972. Aging and Society, Vol. 3. A Sociology of Age Stratification. New York: Russell Sage.

Rychtaříková, J. 2006. „Být svobodnou matkou v České republice?“'In J. Kocourková, L. Rabušic (eds.) Sňatek a rodina: zájem soukromý nebo veřejný? Praha: Universita Karlova, s. 20-44.

Sackmann, R.; Wingens, M. 2001. „Theoretische Konzepte des Lebenslaufs: Übergang, Sequenz und Verlauf.“ In R. Sackmann, M. Wingens (Hrsg.) Strukturen des Lebenslaufs: Übergang - Sequenz - Verlauf. Weinheim und München: Juventa, s. 17-48.

Sackmann, R.; Wingens, M. 2003. „From Transitions to Trajectories: Sequence Types.“ In W. R. Heinz, V. W. Marshall, (eds.) Social Dynamics of the Life Course. New York: Aldine de Gruyter, s. 93-115.

Settersten, R. A.; Mayer, K. U. Jr. 1997. „The Measurement of Age, Age Structuring and the Life Course." Annual Review of Sociology, 23: 233-261.

Shanahan, M. J. 2000. „Pathways to Adulthood in Changing Societies: Variability and Mechanisms in Life Course Perspective." Annual Review of Sociology, 26: 667-692.

Sobotka, T. 2006. „Bezdětnost v České republice.“ In D. Hamplová, P. Šalamounová, G. Šamanová (eds.) Životní cyklus: sociologické a demografické perspektivy. Praha: Sociologický ustav AV ČR, s. 60-78. 
Wyn, J.; Dwyer, P. 2000. „New Patterns of yYouth Transition in Education.“ International Social Science Journal, 52 (164): 147-159.

Zeman, K. 2006. „Vývoj obyvatelstva České republiky v roce 2005،“ Demografie, 48 (3): $153-165$.

\section{Autorka}

Jana Havlíková je doktorandkou na Katedře sociologie FSS MU a současně působí jako výzkumná pracovnice př̀ brněnské pobočce VÚPSV Praha. Svůj odborný zájem soustřed’uje na teorii životního běhu, problematiku přechodu ze školy do zaměstnání a zabývá se též tématem kvality osobních sociálních služeb.

Kontakt: havlikov@fss.muni.cz 